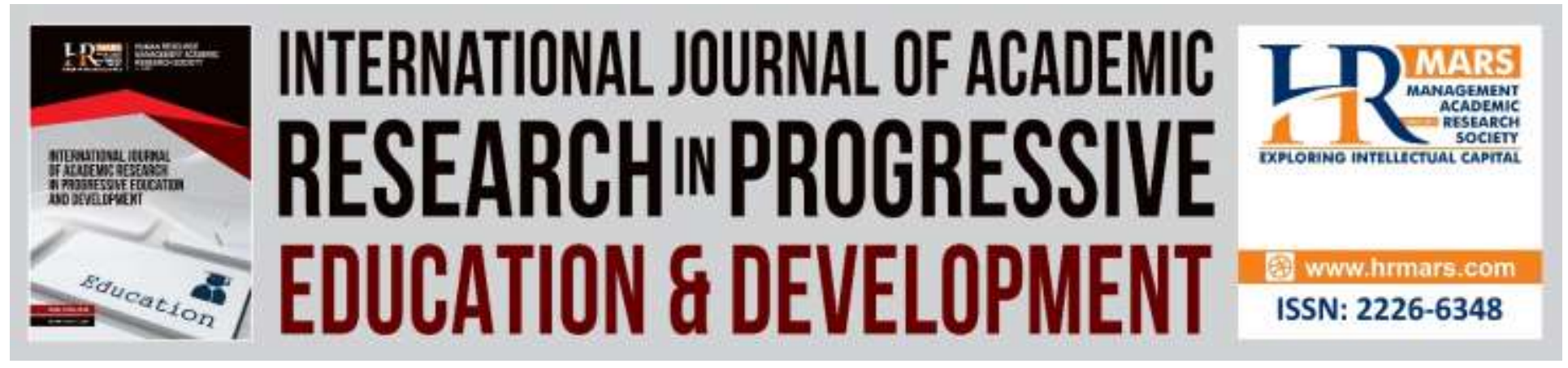

\title{
Mentoring: Improving the Teaching Skills in Playing Recorder among Non-option Music Education Teachers in Kanowit District
}

Janin Janting, Mahayuddin Abdul Rahim

To Link this Article: http://dx.doi.org/10.6007/IJARPED/v9-i2/7295

DOI:10.6007/IJARPED/v9-i2/7295

Received: 28 March 2020, Revised: 30 April 2020, Accepted: 18 May 2020

Published Online: 11 June 2020

In-Text Citation: (Janting \& Rahim, 2020)

To Cite this Article: Janting, J., \& Rahim, M. A. (2020). Mentoring: Improving the Teaching Skills in Playing Recorder among Non-option Music Education Teachers in Kanowit District. International Journal of Academic Research in Progressive Education and Development, 9(2), 217-228.

Copyright: (C) 2020 The Author(s)

Published by Human Resource Management Academic Research Society (www.hrmars.com)

This article is published under the Creative Commons Attribution (CC BY 4.0) license. Anyone may reproduce, distribute, translate and create derivative works of this article (for both commercial and non-commercial purposes), subject to full attribution to the original publication and authors. The full terms of this license may be seen

at: http://creativecommons.org/licences/by/4.0/legalcode

Vol. 9(2) 2020, Pg. 217 - 228

http://hrmars.com/index.php/pages/detail/IJARPED

JOURNAL HOMEPAGE

Full Terms \& Conditions of access and use can be found at http://hrmars.com/index.php/pages/detail/publication-ethics 


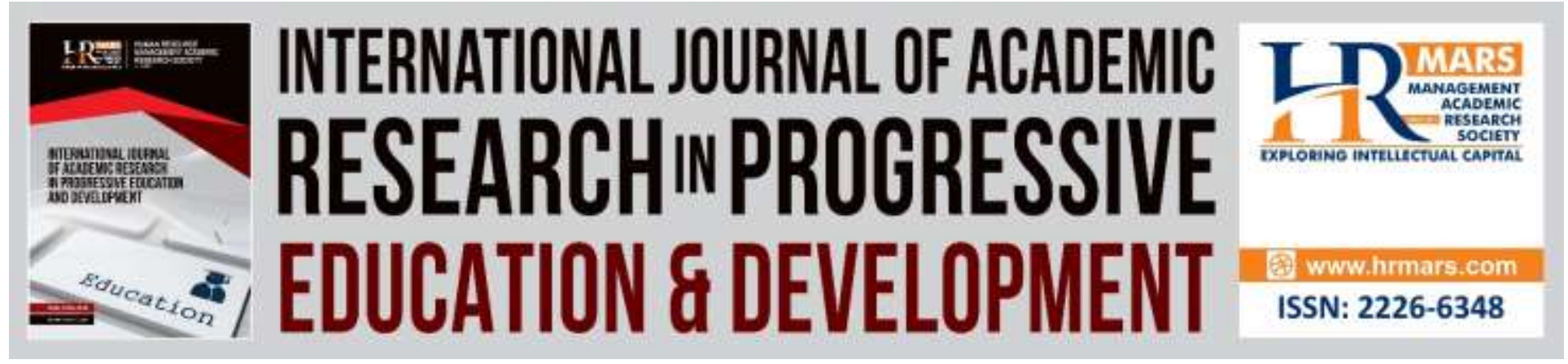

\title{
Mentoring: Improving the Teaching Skills in Playing Recorder among Non-option Music Education Teachers in Kanowit District
}

\author{
Janin Janting \\ Faculty of Music and Performing Arts, Sultan Idris Education University, Tanjong Malim, 35900, \\ Perak Darul Ridzuan
}

\section{Mahayuddin Abdul Rahim}

Faculty of Music and Performing Arts, Sultan Idris Education University, Tanjong Malim, 35900

Perak Darul Ridzuan

\begin{abstract}
This qualitative research is aimed at guiding three non-option Music Education teachers, known as mentees, in the teaching and learning of playing recorder for Year Six from three selected schools in Kanowit district, a district in Sarawak, one of the states in Malaysia. The mentoring method will be used in helping the selected teachers and it will be validated by an experienced lecturer before it is used in guiding the three mentees. An expert of recorder player will be appointed to draft the teaching and learning that would be conducted. The data will be collected through three research instruments: classroom observation, interview protocol and document analysis. The data collected will be analysed, coded and themed, and transcribed into writing. Each transcription will be validated by the participants before they are used in the research. It is hoped that the procedures which will be developed and the mentoring method which will be implemented can be an example to assist the three non-option teachers selected in developing knowledge and skills to conduct their teaching and learning of playing recorder in particular, Kanowit district, Sarawak.
\end{abstract}

Keywords: Non-Option Teachers, Music Education, Playing Recorder, Mentoring Method, Mentees Distribution Centre, Enterprise, SME.

\section{Introduction}

Recorder is one of the musical instruments used by students in Music subject to assist teachers in the teaching and learning of Music subject in the implementation of the Standard-Based Curriculum for Primary Schools (Kurikulum Standard Sekolah Rendah - KSSR). Based on DSKP Pendidikan Muzik Tahun 6, the Music subject conducted in schools consists of four elements: 
Musical Experience, Music Production, Appreciation of Music and Reading and Writing of Notation (Kurikulum Standard Sekolah Rendah, 2019). An early research survey conducted discovered that music teachers in primary schools in Kanowit district are among teachers who are non-option in music.

\section{Research Background}

This study will be conducted in three selected schools in Kanowit district, a small town located in the rural area in which agriculture is the main job of the people. These three schools neither has a music room nor musical instruments which are needed for the process of teaching and learning of music. Recorders are not provided though they are the most needed musical instrument in implementing Music Education subject of KSSR. The absence of trained music teachers makes the matter worse and weaken the spirit of students to own a recorder and learn how to play recorder. The participants for this study are three non-option music education teachers. These teachers has given their best effort to complete the syllabus of music subject, however they faced problems in the process of teaching and learning of playing recorder. Being the non-option teachers in music, they lack the basic skills and knowledge about music education such as posture, fingerings, articulation, embouchure, tone and musical notation. The basic skills and knowledge about music are compulsory and needed to be mastered by all music teachers apart from the talents and high interests in music. In addition, a music teacher also needs to have good class control and be a facilitator to the students. However, this is not the case for the selected participants.

According to Ismail and Subki (2014), teachers' skills in controlling an effective process of teaching and learning are able to create comfortable, fun and conducive learning environment throughout the process of teaching and learning. In addition, Mazzocchi (2015) stated that "Great music teachers understand that every single child is capable of becoming proficient at their craft" (p. 2). Teachers need to be guided to enable them to conduct the teaching and learning process as stated in KSSR (2019). For this purpose, Mentoring method is among the methods which is proven in helping teachers to develop their knowledge and skills in particular to those non-option teachers who have problems in the process of teaching and learning of music education. Therefore, in this study, the mentoring method (mentor-mentee program) will be applied to develop the skills in the teaching and learning process of playing recorder among nonoption music education teachers. According to Benson (2008) and Conway (2003), mentormentee program was suggested as one of the effective ways for teachers who are new in the transition process from new teachers to a professional music educator. Mentoring method will assist music teachers to understand and share a number of approaches in implementing effective teaching and learning process. According to Alias (2015), a mentor will share the expertise with a mentee, explain or become a model to a mentee, demonstrate effective ways or methods, and does not encourage a mentee to practice something new. Mentoring covers the aspects of training, guiding, counselling and instil cooperation with other individuals. 
INTERNATIONAL JOURNAL OF ACADEMIC RESEARCH IN PROGRESSIVE EDUCATION AND DEVELOPMENT

Vol. 9, No. 2, 2020, E-ISSN: 2226-6348 @ 2020 HRMARS

\section{Problem Statement}

The skills of music teachers are really needed in the teaching and learning process of music education in schools. Based on the early research survey conducted, it was discovered that these teachers did not conduct the teaching and learning process of playing recorder properly. During the teaching of playing recorder process, the teachers did not use the score of the songs played. Instead, the teachers used the alphabets A, B, C as the note in guiding their students to blow the recorder. The students were very weak in reading the scores. Even there were some students who still could not recognize the notes. In terms of blowing the recorder, most students only blew without correct control of air and resulted in producing inaccurate sounds and pitch.

In terms of fingering, it is obvious that the teachers were weak in the recorder fingering. The teachers did not cover the correct holds on the recorder. This resulted in producing discordant tone and unfulfilled notes. In addition, the teachers were not practicing correct standing of playing recorder while playing it. The teachers were not teaching based on scores, instead the students were blowing the recorder based on the alphabets $(A B C)$.

The findings from the early research survey also discovered that the non-option teachers did not have proper breathing control when they blew the recorder. This led to them not producing good quality tone while playing the recorder. The uncontrolled recorder playing had resulted in students blowing the recorder as they wished without protocol. The strategy applied by all the three teachers in all the schools could not help the students to play the recorder in a proper way. If these problems continued, the teaching and learning would be boring, thus led to the students losing their interests to learn. According to Syed and Ahmad (2014), they stated that teaching strategies include approaches, techniques and delivery methods. As a teacher who is responsible to teach Music Education for Level 2 (upper primary), the teacher himself must have sound skills in theory of music and practical in music especially in playing the recorder. This is important so that the music teacher can apply suitable teaching and learning methods in teaching students about the recorder in particular in the teaching and learning process of playing recorder.

\section{Research Purpose}

The purpose of this study is to guide three non-option Music Education teachers in Kanowit district in conducting the teaching and learning process of playing recorder among Year Six students through Mentoring method.

\section{Research Objective}

i. Drafting the suitable Mentoring procedures in the teaching and learning process of playing recorder for Year 6 non-option music teachers.

ii. Implementing the suitable Mentoring method in guiding the non-option music teachers to improve the teaching and learning process of playing recorder for Year Six.

iii. Observing to what extend the Mentoring method can assist the non-option teachers in applying the strategy in the teaching and learning process of playing recorder.

\section{Research Questions}

i. What are the suitable Mentoring procedures implemented in this study? 
Vol. 9, No. 2, 2020, E-ISSN: 2226-6348 @ 2020 HRMARS

ii. How is mentoring method implemented in guiding the non-option music teachers to improve their teaching and learning process of playing recorder for Year Six?

iii. To what extend can mentoring method assist the non-option teachers in applying the strategy in the teaching and learning process of playing recorder?

\section{Significant of the Research}

This study is conducted to assist the non-option music education teachers in Kanowit district in conducting the teaching and learning process of recorder for Year 6 with more confidence. It is hoped that after completing this study, the mentoring method will give positive effects and impact to the participants to improve their teaching and learning process of playing recorder, thus develop their own skills in playing the recorder. Apart from the participants themselves, the findings from this study is also hoped to benefit other music teachers in Kanowit district and as a guideline and also as a reference in the future.

\section{Research Limitation}

Non-option Music Education teachers in Kanowit district are chosen as the research participants. There are only three non-option music teachers selected in this study among all the schools in Kanowit district. Therefore the findings of this study cannot be generalized to the whole population of non-option music education teachers in Kanowit. Furthermore since this study only focuses on non-option music education teachers, this finding cannot be generalized to other music education option teachers.

In this study, mentoring method is used to assist the participants in improving their teaching and learning process of playing recorder, the findings cannot be generalized to other non-option music education teachers due to different context than Kanowit district. Other schools might have special rooms for music education and might provide recorders for their students. Therefore, the mentoring method might not be as effective as it is with the selected participants. The findings might be different for other groups of population depending on different contexts, different background of teacher-participants and different support received by schools.

\section{Problems of Learning and Teaching of Playing Recorder}

Zimmerman (2017), wrote about the importance of teaching recorder in schools. The teaching of recorder in schools is important to expose students to the techniques of playing recorder, notation reading and correct techniques of playing recorder. According to Birnie (2014), as a music teacher, she asked her friends of what did they still remember about their basic experience of music education. Her friends replied that they still remembered the basic of playing recorder when they were at primary schools. This indicated that they only had the basic knowledge in playing recorder and had never received any specific trainings in playing recorder. American OrffSchulwerk Association (AOSA) (2017) stated that they trained teachers in the whole world by using Orff-Schulwerk method in which the use of recorder is emphasized in the trainings. In the AOSA Teacher Education Standard Curriculum, it mentioned the background and the story of how Carl Orff started to record his teaching. Although they are trained teachers in the pedagogy of music, they still have to practice playing and use recorder in their teaching. This reveals how difficult correct teaching of recorder is because in order to teach recorder, one needs good talent 
and high skills of playing the recorder. According to Faulkner (2014), music teachers need to develop their skills in terms of theory and practical so that they do not only understand certain things about music but they can also conduct and teach the practical part of music. According to Southcott (2016), most teachers did not focus on embouchure and correct tonguing techniques. This lead to students practicing wrong ways of playing recorder. According to Wood (1992), a music teacher needs required knowledge and skills before they are able to conduct certain teaching. Based on all mentioned above, it is obvious that it is important and crucial for all music education teachers to master the practical skills of how to play the recorder so that they can teach their students the correct techniques in playing the recorder. Therefore this study is important to be conducted to help the selected participants to develop their teaching and learning process in playing the recorder and to master their practical skills and techniques of playing the recorder.

\section{Mentoring Method}

The word 'Mentor' is originated from Greek and it is a name of a person who was given the responsibility by Odysseus (Ulysses) to care for his son, Telemachus, aged 10 years old (Irby \& Boswell, 2016). His roles were complex: a protector, an adviser, a teacher and parents to his son. Whoever was considered intelligent in guiding people, giving advice, being a counsellor and a 'role model' in building good personality can be an effective mentor. According to Cornell (2003), a mentor is an experienced class teacher who welcome new teachers who are going through their trainings.

This mentor program is also known as mentor-mentee program. As mentioned by Holliday (2001), many mentor-mentee programs have been implemented in assisting the development of knowledge and skills among new teachers and students. It has also been suggested as an effective transition period from new music teachers to professional music teachers. Conway (2003) stated that mentoring is suggested as a way to assist in the professional development of new teachers. Pittman (2007) explored the perceptions about mentoring among teachers and discovered that mentoring helps in developing the best teaching practice. Conway (2003) continued his investigation with the perceptions of senior music mentors about their work commitments. Chaffin and Manfredo (2010) investigated the perceptions of trainers about their mentors and their feedback on their experiences with their instruments. There are many articles about mentoring programs and their effectiveness in the teaching practices. However, the focus on the effectiveness of mentoring in teaching certain music skills has received the attention.

According to Smith (2005), effective mentoring is when the relationship between mentor and mentee is like a family which includes (a) professional caring (b) sharing of knowledge and experiences, (c) attitude and practices (d) teaching practice with in experienced ones. Good communication is important in building the relationships and sharing knowledge and this can be achieved through the understanding between mentor and mentee. Through effective communication, mentor can deliver the knowledge and information effectively.

Jacobs (2008) suggested that effective Mentor model should be matched to students' needs in which observations and understanding are the beginning key to success. Conway (2003) proposed eight efficiency towards effective mentoring: (i) understand the roles of mentor, (ii) improve collaborative learning, (iii) give encouragement, (iv) develop self-performance (coaching 
skill), (v) display and complete teaching needs, (iv) demonstrate and guide, (vii) effective classroom management and display elements of individual differences, (viii) build professional relationship.

Jacobs (2008) mentioned that mentors are responsible to design effective teaching model for their own classes, conduct frequent observations towards new teachers, and start meetings with the purpose for discussions and constructive feedback with all the selected mentees. Good potential mentors need to identify and understand the key so that this Mentoring program is effective and impactful.

\section{Cognitivism Theory}

The theory chosen for the theoretical framework of this study is Cognitivism. According to Hussin (2013), cognitivism is based on thinking, the inner mental process which enables human to obtain, identify, access and remember knowledge stored to be reused (Amir, 1986; Hassan, 1993; Sulaiman, 1997; Mahani, 2004; Reed, 2004; Solso et al. 2005).

The cognitive learning theory explains learning as a knowledge change stored in the memory. This theory was poineered by Piaget (1954). According to him, a person learns by giving the attention to a stimulus. For example, the wind which causes the branches of a tree to move, mentally a person will be comparing to the same picture known to his or her and aware on how it is matched to the cognitive structure of the memory. By doing this, a person will build a new concept relating to the new picture and keep it in the memory according to how the concept is matched to the previous concept.

According to Hussin (2013), the cognitive learning theory founded by Bruner dan Simon in 1950s focuses on bulding the coding system which will allow transfering, promote memory and problem solving and motivate students. When students experience the teaching and learning process, they will code each experience received and store it in the short term memory as well as the long term memory. The changes of behaviours are used as an indication towards the process happening in their thinking. The cognitive theorists have identified that learning involves the connection through continuous and repetitive practices.

Based on the elements of the learning cognitive theory, this theory is chosen for this study as it is suitable to be used among the selected music education teachers. By going through the process of mentoring method, the selected participants will go through active mental process in receiving and storing their newly received experience and knowledge in their short term as well as their long term memories. The changes of their teaching and learning process is expected to happen by applying the new and correct techniques in playing the recorder.

\section{Methodology}

According to Yusof et al. (2015), research design refers to a set of decision related to the topic being studied, selected population and method used based on the objectives set. The research design for this study is a case study. As stated by Lichtman (2011), "A case study is based on the type of case chosen (ordinary, example, extraordinary and unique)" (p. 109).

According to Glogowska (2011), qualitative method is used to study and examine phenomenon in a non-objective way because of similar elements from the researcher's attitude, belief and values. For this study, a descriptive case research design will be used to understand 
certain cases under observation (Grynszpan, Murray \& Llosa, 2011). In this study, understanding the case study will be conducted through classroom observation: classroom observations will be conducted with all the three participants. According to Yusof et al. (2015), qualitative research applies an inductive approach which is conducted to understand in depth about how certain things are the way they are and what are the perceptions of the subjects about the context of the study. Qualitative approach usually produces plenty of information, detailed information and deep understanding about certain cases or situations. Lebar (2014) also stated that qualitative methodology is a powerful tool to increase our understanding about teaching and learning.

\section{Mentoring Procedures}

i. Procedure 1 (Individual Meetings)

ii. $\quad$ Procedure 2 (Meetings with All Mentees)

iii. Procedure 3 (Reading and Writing of Notation)

iv. Procedure 4 (Posture Training and Practice)

v. Procedure 5 (Breathing and Tonguing Practice, Embouchure)

vi. Procedure 6 (Practice on Recorder Fingering based on Scores)

vii. Procedure 7 (Playing Recorder not $E, F, G, A, B, C$ and $D^{\prime}$ )

viii. Procedure 8 (Playing Recorder not $D, E, F, G, A, B, C^{\prime}$ and $D^{\prime}$ ).

ix. Procedure 9 (Playing Recorder not Playing C, D, E, F, G, A, B, C' and $D^{\prime}$ ).

$\mathrm{x}$. Procedure 10 (Classroom Observations in Schools)

\section{Duration of Mentoring Procedures}

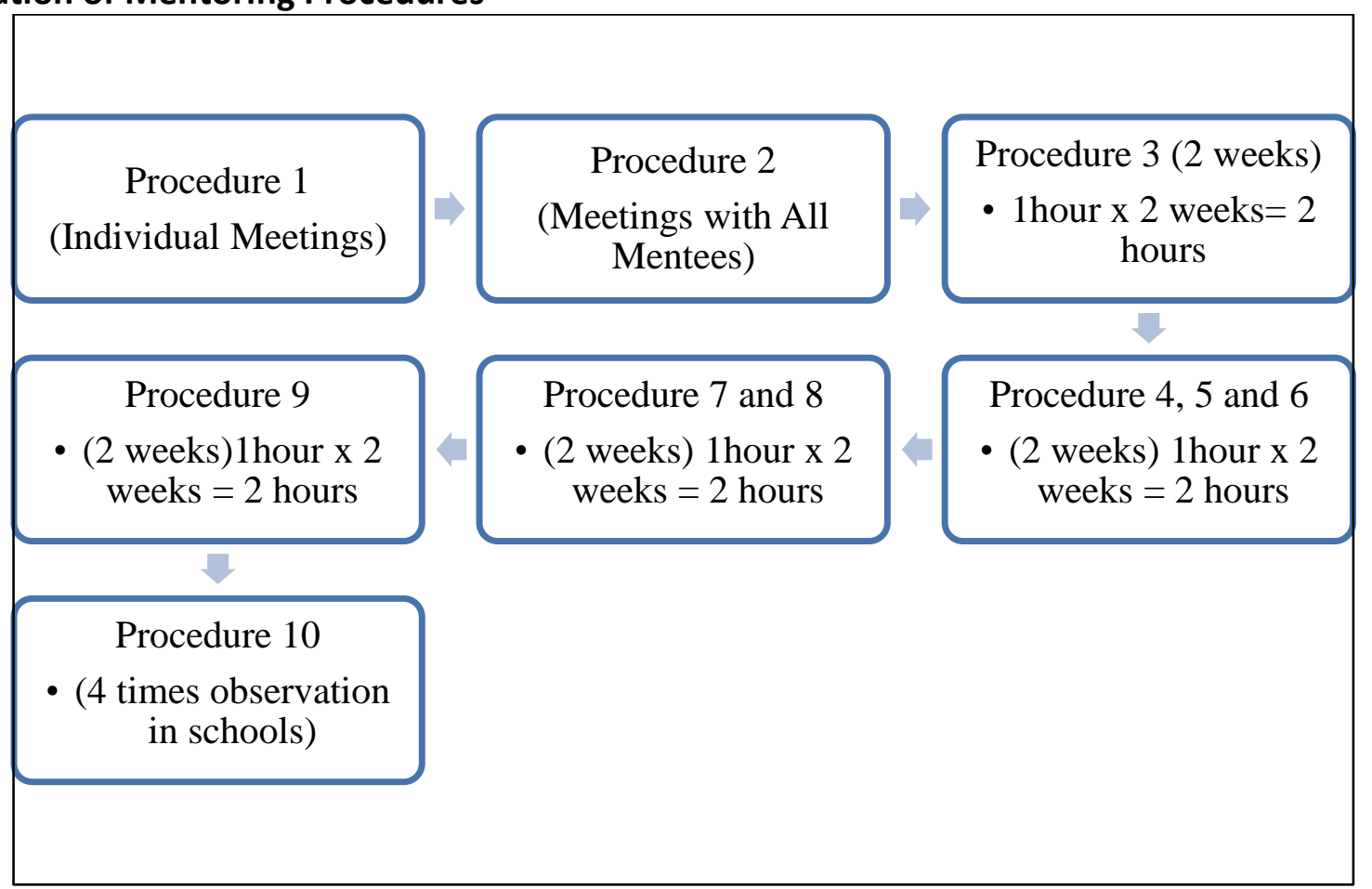

Figure 2. Duration of Mentoring Procedures 
INTERNATIONAL JOURNAL OF ACADEMIC RESEARCH IN PROGRESSIVE EDUCATION AND

DEVELOPMENT

Vol. 9, No. 2, 2020, E-ISSN: 2226-6348 @ 2020 HRMARS

\section{Research Subject}

The subjects of the study are three teachers: two male and one female teachers. They are from different options: one male English teacher, one female Mathematics teacher and one Malay language teacher. All these three teachers do not have formal education in Music Education. However, all of them have between 13 to 25 years of experience in teaching.

\section{Research Location}

Three schools are selected because they were accessible to the researcher and this ease the completion of the study conducted. The selection of these three schools is suitable because they are easily accessed to the researcher. In addition, these three schools are selected because they share a number of similarities in terms of population, subjects and background: almost the same number of students, no music class reserved for the teaching and learning process of music education and the majority of the students are from Iban tribe.

\section{Data Collection Procedure}

For data triangulation, three research instruments will be used: classroom observation, semistructured interview and document analysis. The purpose of all the instruments are to obtain the data needed to answer all the research questions. According to Jasmi (2012), "field notes and the researcher's diary are the main supports to validate the field work conducted in a qualitative study" (p. 1-2). This study employs a fieldwork study. In addition, according to Ismail (2015) through fieldwork study, a researcher observes and note an individual or a group's behaviour in their natural settings.

Apart from the classroom observations, interview sessions will also be conducted with all the participants. Semi-structured interview is selected because according to Idris (2013), the sequence of the questions, the way the questions were asked and the form of the questions can be changed depending on the reactions and the feedback of the respondents. By doing this, the mentees would feel more comfortable and will not be offended with all the questions asked. Each interview session will be audio recorded and these audio recordings will be listened to repeatedly for transcriptions purposes.

Another research instrument will be used in this study is document analysis. Some of the documents which are included in the document analysis as the research instrument are reports, minutes of meetings, syllabus and publications (Idris, 2013). As far as this study is concerned, some of the documents which will be analysed are the DSKP of Music Education for Year 6, the teachers' daily lesson plans and also the Music Theory Book.

\section{Data Analysis Procedures}

As mentioned before, the data for this study will be collected through three research instruments: classroom observation, interview protocol and document analysis. Both the interview sessions and classroom observations, will be analysed immediately after the completion of the first observation. According to Creswell (2012), each time the transcriptions were read, appropriate coding, instincts or issues were noted for further analysis later on. Field notes, audio and video which will be recorded are transcribed according to the sequence of the 
procedures and the date the data are obtained. All these notes and transcriptions will be read frequently to ensure accurate and valid data are collected.

According to Tobi (2017), interviews can be analysed using the content analysis techniques based on words, coding and a few analytical strategy to analyse the content of the interviews. The coding and thematic process are conducted by making the research questions as guidance (Miles \& Huberman, 1994). According to Tong (2014), the data coding process started by dividing the data text into categorized segments. As for this study, the segments will be marked with codes which will then grouped according to themes, for examples, code 01 (observation 1), INT (interview), ME1 (mentee 1), ME2 (mentee 2), ME3 (mentee 3) and R (researcher). Based on the literature reviewed, a list of themes was prepared earlier as a guide and more new themes will be added to answer the research questions. This is important because the coding and thematic process are not ready data to be analysed, but continuously emerging throughout the process of collecting data (Miles \& Huberman, 1994; Creswell, 2012).

The DSKP (Standard Document for Curriculum and Assessment) of Music Education for Year 4, 5 and 6 and the daily lesson plans of the mentees will be analysed. This is to examine the techniques applied by the selected teachers in the planning of their music education lessons: whether correct techniques will be applied to teach and train their students to play the recorder.

\section{Conclusion}

This study employs a qualitative approach which focused on case study. The research participants are three non-option music education teachers in Kanowit district. Triangulation of data is conducted to ensure accurate and valid data were collected. The research instruments will be used in this study are classroom observation, interview protocol and document analysis. The teaching and learning theory is used during the process of guiding and observations to examine the effectiveness of the theory. All the data collected: field notes, audio and video recordings, and interviews will be transcribed according to the sequence of the procedures and the date when the data are collected. All the interviews will be recorded. The notes and the transcriptions will be read repeatedly to ensure the validity of the data collected.

\section{Acknowledgement}

We would like to thank everyone involved in the publication of this article not forgetting the Faculty of Music and Performing Arts and Sultan Idris Education University who have put their trust in our study. Finally many thanks go to our beloved family and friends for all their invaluable encouragement and supports.

\section{Corresponding Author}

Janin Anak Janting

Faculty of Music and Performing Arts, Sultan Idris Education University

Email: janinjanting.jj@gmail.com 
INTERNATIONAL JOURNAL OF ACADEMIC RESEARCH IN PROGRESSIVE EDUCATION AND

DEVELOPMENT

Vol. 9, No. 2, 2020, E-ISSN: 2226-6348 @ 2020 HRMARS

\section{References List}

Book

Salhah, A., \& Ainon, M. (2005). Guru Sebagai Mentor. Selangor Darul Ehsan: PTS Publishing House.

Alias, A. R. (2015). Modul Latihan ASAS Coaching \& Mentoring. Kuala Lumpur: Institut Aminuddin Baki, Bandar Enstek.

Jonathan, A., \& Milicent, P. (2011). Penulisan Tugasan \& Tesis Edisi Ke-4. Perak: Universiti Pendidikan Sultan Idris Tanjong Malim

Kurikulum, B. P. (2014). Dokumen Standard Sekolah Rendah. Kuala Lumpur: Kementerian Pendidikan Malaysia

Ismail, S., Mustapa, S., \& Miskon, A. S. (2014). Guru Dan Cabaran Semasa. Selangor Darul Ehsan: Penerbitan Multimedia Sdn. Bhd.

Faulkner, J. (2014). Teaching the Recorder in a 4th Grade Inclusion Setting. Los Angeles: Silver Lake College.

Grynszpan, D., Murray, V., \& Llosa, S. (2011). Value of case studies in disaster assessment? Prehospital and Disaster Medicine, 26(3), 202-205

Holliday, M. (2001). Coaching, Mentoring And Managing: A Coach Guidebook (Rev.ed). Franklin Lakes. Londan: Career Press.

Idris, N. (2013). Penyelidikan Dalam Pendidikan. Shah Alam, Selangor: McGraw-Hill Education (Malaysia) Sdn. Bhd.

Ismail, R. (2015). Metodologi Penyelidikan: Teori dan Praktis. Bangi: Universiti Kebangsaan Malaysia.

Jasmi, K. A. (2012). Metodologi Pengumpulan Data Dalam Penyelidikan Kualitatif. Kursus Penyelidikan Kualitatif Siri 1 2012, 1.

Lebar, O. (2014). Penyelidikan Kualitatif Pengenalan Kepada Teori Dan Metode. Tanjong Malim, Perak: Universiti Pendidikan Sultan Idris.

Licthman, M. (2011). Understanding and Evaluating Qualitative Educational Research. United Kingdom: SAGE Publication, Inc.

Miles, M. B., \& Huberman, A. M. (1994). Qualitative Data Analysisan Expanded Sourcebook. 2nd Edition. California: SagePublications.

Piaw, C. Y. (2011). Kaedah Dan Statistik Penyelidikan Buku 1 Kaedah Penyelididikan. Malaysia: McGraw-Hill (Malaysia) Sdn. Bhd.

Tobi, S. U. (2017). Kajian Kualitatif dan Analisis Temu Bual. Kuala Lumpur: Aras Publisher.

\section{Journal}

American Orff-Schulwerk Association. (2017). AOSA Teacher Education Curiculum Standard. Recorder Introduction.

Benson, M. A. (2008). Effective mentoring for new music teachers: An analysis of the mentor programs for new teachers as described in the literature. Update:

Applications of Research in Music Education, 26(2), 42-49.

Bernard, R. (2010). The Rewards Of Teaching Music in Urban Settings. Music Educators Journal; Mar 2010; 96, 3; ProQuest, 2.

Birnie, R. (2014). Compasition And Recorders. Music Educators Journals, 100, 73-78. 
INTERNATIONAL JOURNAL OF ACADEMIC RESEARCH IN PROGRESSIVE EDUCATION AND

DEVELOPMENT

Vol. 9, No. 2, 2020, E-ISSN: 2226-6348 @ 2020 HRMARS

Chaffin, C., \& Manfredo, J. (2010). Perceptions of preservice teachers regarding feedback and guided reflection in an instrumental early field experience. Journal of Music Teacher Education, 19(2), 57-72.

Creswell, J. W. (2012). Educational Research: Planning, Conducting and Evaluating Quantitative and Qualitative Research. Fourth Edition. Boston: Pearson.

Conway, C. M. (Ed.). (2003). Great beginnings for music teachers: Mentoring and supporting new teachers. Reston, VA: MENC.

Glogowska, M. (2011). Paradigms, pragmatism and possibilities: Mixed-methods research in speech and language therapy. International Journal of Language \& CommunicationDisorders, 46(3), 251-260.doi:10.3109/13682822.2010.507614

Jacobs, J. N. (2008). Constructing a model for the effective mentoring of music educators. Journal of Music Teacher Education 17(2), 60-68.

Sarrazin, N. (2018). Music And The Child. Kuala Lumpur: Creative Commons AttributionNonCommercial-ShareAlike 4.0 International License.

Smith, M. K. (2005). Modern mentoring: Ancient lessons for today. Music Educators Journal, 92(2), 62.

Tong, Ho Ho., Murshidi, Rahmah, We., Gan L., Awal, A., Yew, L. H., Brodi, J., Saidi, S., Abang, S. (2014). Asas Penyelidikan Tindakan: Teori Dan Amalan. Kota Samarahan: Jabatan Penyelidikan Dan Inovasi Profesionalisme Keguruan.

Zimmerman, K. S. (2017). Potential Benifits Of Teaching With Recorders. A Teachers' Perspective, 9.

Technical and Research Reports

Mazzocchi, T. (2015). (C) 2016 National Association for Music Education. Didapatkan October 17, 2016, daripada National Asscoiation For Music Education: http://www.nafme.org/whatmakes-a-great-music-teacher/

Pittman, C. K. (2007). An analysis of beginning teachers' perceptions of the mentoring program in a North Carolina public school system. (Doctoral Dissertation, Nova Southeastern University, Florida). Retrieved from http://p8080-

marps.library.nova.edu.ezproxylocal.library.nova.edu/ MARPs/mydefault.aspx 